\title{
Die hermeneutiek van die belydenisskrifte
}

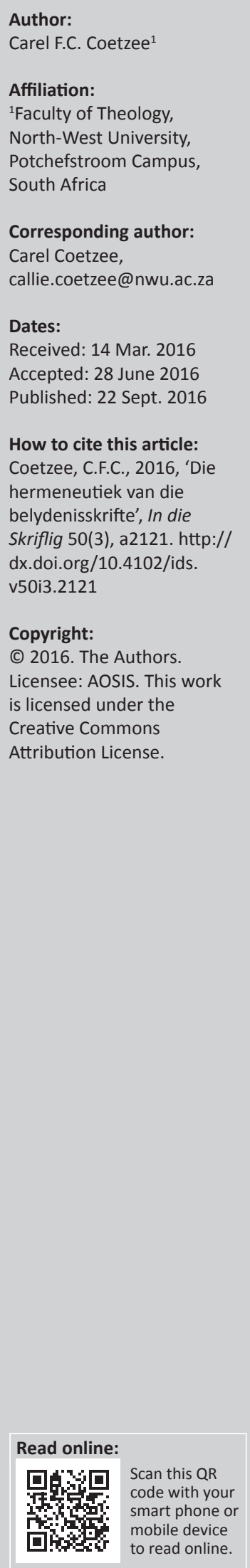

The hermeneutics of the reformed confessions. The purpose of this article, in the first place, is to honour the work that Prof Gert (Jorrie) Jordaan has done over several decades, especially in the field of hermeneutics. Secondly, the article wants to make a contribution regarding another aspect of hermeneutics, namely the hermeneutics of the reformed confessions. A close relationship exists between Scripture and the confessions. The confessions is a summary or 'authoritative commentary' on the core truths of the doctrine in Scripture. They are ecclesiastical documents, authoritative and binding on officials and church members of churches in the reformed tradition. They are commentaries or interpretations, but also need to be interpreted. Due to their unique character and function, the hermeneutics of the confessions is of utmost importance. The article formulates ten guidelines that are, in the view of the author, essential for the contemporary interpretation of the confessions.

\section{Inleidende opmerkings}

Die teologiese vakdissipline bekend as Hermeneutiek het nog altyd 'n belangrike plek in die teologiese ensiklopedie ingeneem. Onder hermeneutiek word verstaan die metodes en tegnieke wat gebruik word om geskrewe tekste te interpreteer. 'In die teologie het hermeneutiek as 'n gespesialiseerde toepassingsveld ontwikkel omdat Bybelse tekste so duidelik na uitleg vra' (Lategan 2008:449-450). Hierdie artikel wil aan die een kant die belangrike werk in herinnering roep wat prof Gert (Jorrie) Jordaan oor 'n aantal dekades op die terrein van die gereformeerde hermeneutiek verrig het, en aan die ander kant poog om 'n bydrae te lewer oor 'n aspek van die hermeneutiek wat aandag verdien, naamlik die hermeneutiek van die belydenisskrifte.

Reeds in sy inougurele rede het Jordaan (1991) gehandel oor die onderwerp 'Skrifbeskouing: deurslaggewende faktor by Skrifverklaring'. Wat sy akademiese loopbaan betref, het hy toe reeds die volgende voorneme uitgespreek (Jordaan 1991):

Vanuit hierdie Skrifbeskouing is my strewe ' $n$ omvattende hermeneutiese metodologie, waarin nie een faset van die teks verabsoluteer word of tot verklaringsprinsipe verhef word nie. Van die moderne ontwikkelinge en verfyninge in die hermeneutiek sal gebruik gemaak word en daarop voortgebou word, maar steeds binne die raamwerk van genoemde Skrifbeskouing. (bl. 30)

Jordaan se uitbouing van die vakdissipline is verder steeds beheers deur die belydenis, 'In die eerste en die laaste instansie is betroubare verklaring van die Skrif afhanklik van die Heilige Gees as die eintlike Verklaarder van die Skrif' (Jordaan 1991:30).

Gedurende sy lang en geseënde akademiese loopbaan aan die Teologiese Skool van die Gereformeerde Kerke in Suid-Afrika (Potchefstroom) en die Fakulteit Teologie van die Potchefstroomse Universiteit vir Christelike Hoër Onderwys, later die Noordwes-Universiteit, het Jordaan uitstekende studieleiding aan studente in die Hermeneutiek gegee (vgl. onder andere sy uitgebreide studiegids vir die module Herm875 - Jordaan s.j.; en die samevattende opsomming daarvan vir nagraadse studente - Jordaan 2015).

Die Skrifbeskouing wat Jordaan as eie vertrekpunt neem in die beoefening van die Hermeneutiek, word deur homself as gereformeerd-fundamenteel bestempel (Jordaan 1991):

Dit beteken dat ek die Bybel as betroubare geïnspireerde openbaring van God handhaaf, as geslote kanon, as eenheid, as 'n voluit menslike boek met volmaakte Goddelike gesag, wat binne sy konteks verstaan moet word, 'n konteks wat in sy wydste sin saamgevat is in die Gereformeerde belydenisskrifte. (bl. 29)

Wat hierdie artikel betref, is Jordaan se verwysing na en onderskrywing van die gereformeerde belydenisskrifte veral relevant en belangrik. 


\section{Probleemstelling}

Uit die aanhaling hierbo blyk dit duidelik dat daar, volgens Jordaan, die nouste verband bestaan tussen die Skrif en die gereformeerde belydenisskrifte ${ }^{1}$ as die konteks waarbinne die Skrif verstaan moet word. Jordaan bevind hom met hierdie standpunt binne die gereformeerde tradisie waar die belydenisskrifte aanvaar en gehandhaaf word, omdat (quia) dit in ooreenstemming met die Skrif is. ${ }^{2}$ Die belydenisskrifte kan as kerklike dokumente gesien word wat op die Skrif gebaseer is. As sodanig het dit kerklike gesag - 'n aspek waarop ons later in die artikel sal terugkom. Die belydenisskrifte as norma normata is dus altyd ondergeskik aan die Skrif as norma normans, maar dien terselfdertyd as noodsaaklike riglyn vir die verklaring van die Skrif en die beoefening van die gereformeerde teologie. Janse van Rensburg en Dreyer (2016) bestempel die belydenis onder andere as:

Samevatting van die kern van die Christelike geloof; norm vir die verkondiging; basis van die kategese; maatstaf vir teologiese onderrig; rigsnoer vir kerklik-teologiese uitsprake; afgrensing teen teologiese dwaling; rigtingwyser vir die gebruik en ontwikkeling van kerklik-teologiese taal. (ter perse)

Insiggewend is ook die opmerking van Lategan (2008:450) dat die belydenisskrifte as 'n vorm van hermeneutiek beskou kan word.

In die postmoderne milieu van vandag kom die kwessie van die gesag van en binding aan die belydenisskrifte egter al hoe meer in die gedrang. ${ }^{3}$ Vrae soos die volgende word toenemend gevra:

Is die belydenisskrifte nog relevant vir hierdie tyd? Moet dit steeds gehandhaaf word? Kan dit van gelowiges verwag word om hulle steeds deur instemming daaraan te bind? Hoe raak dit die beoefening van teologie en kerkwees in hierdie tyd? (Coetzee 2010:31) $)^{4}$

Uiteenlopende antwoorde word op hierdie en ander vrae gegee. Daar is diegene wat gedeeltes van die belydenisskrifte openlik bevraagteken en verwerp. So verklaar Van Niekerk (2005:16): 'Die tradisionele belydenisskrifte van die gevestigde kerke bevat myns insiens 'n hele aantal artikels wat nog kwalik ernstig opgeneem kan word deur moderne mense ...'.

Dan is daar diegene wat die binding aan die belydenis in die beoefening van die teologie as wetenskap as belemmering of verknegting ervaar (vgl. onder andere Müller 2006:5).

Daar is ook die standpunt dat die belydenisskrifte verouderde dokumente is wat gekonstrueer is op die kennis wat bestaan

1.Alhoewel die artikel deurgaans die term gereformeerde blydenisskrifte gebruik, is ek van oordeel dat dieselfde riglyne vir verklaring ook van toepassing is op die verskeidenheid belydenisskrifte wat in die internasionale gereformeerde wêreld bestaan.

2.Daar word later in die artikel teruggekom op die onderskeid tussen die quia- en quatenus-standpunte rakende die belydenisskrifte.

3.Vir ' $n$ meer volledige oorsig oor die saak van belydenisgebondenheid in ' postmoderne era en relevante literatuur word verwys na Coetzee (2010:27-45).

4. In die betrokke artikel van Coetzee word in besonderhede op hierdie vrae ingegaan. Vir die skopus van hierdie artikel is dit nie direk relevant nie. het in die tyd van hulle ontstaan. Die wetenskap het egter intussen, volgens hierdie standpunt, baie meer kennis na vore gebring (vgl. Snyman 2007:19). Die belydenisskrifte word verder verdink van die weerhouding of 'onbehoorlike manipulasie van inligting ter wille van die handhawing van 'n bepaalde leerstuk' (Snyman 2007:120).

Verder is daar ook diegene wat steeds die binding aan die belydenis wil handhaaf (vgl. onder andere Sproul 2006:vii). Du Plooy (1982:210) beklemtoon die feit dat die belydenis die eintlike saambindende faktor tussen kerke is. Dit is die akkoord van kerklike gemeenskap en as sodanig bewaar dit die eenheid van die kerk (Feenstra 1966:10; vgl ook Van Genderen s.j.: 40). Die belydenis is niks minder nie as deel van die wese van die kerk (vgl. onder andere Coetzee 2013:275-293). Heyns (1977:164) gaan so ver as om die belydenis die 'hart van die kerk' te noem. In die belydenis spreek die kerk homself uit (Heyns 1977:156). 'Die kerk is na sy wese ' $n$ belydende gemeenskap' (Jonker 1994:3) en het dus 'n konfessionele karakter (Heyns 1977:151-168).

Hierdie artikel word vanuit bogenoemde gereformeerde (reformatoriese) paradigma geskryf. Te midde van die uiteenlopende vrae rondom die gesag van en binding aan die belydenisskrifte waarna hierbo verwys is, val die fokus op 'n ander relevante aspek, naamlik die hermeneutiek van die belydenisskrifte self. Die vraag is of daar nie ook bepaalde hermeneutiese reëls vir die belydenisskrifte geld wat die verklaring daarvan vandag steeds relevant maak nie.

In hierdie verband het verskeie publikasies, alhoewel vanuit verskillende hoeke, reeds gepleit vir die 'korrekte' interpretasie van die belydenisskrifte vir ons tyd. Volgens Hofmeyr en Van Niekerk (1987:12, met verwysing na Van Huyssteen) moet belydenisskrifte hermeneuties geïnterpreteer word vir ons tyd. Von Loewenich (1969:7) vestig die aandag op die eis vir die ontmitologisering van die belydenisskrifte deur 'n eksistensiële interpretasie.

Die skrywer van hierdie artikel het dit in 1988 gewaag aan 'n artikel oor 'Die interpretasie van die belydenis' in die lig van 'n 'nuwe' Skrifbeskouing wat op daardie stadium veral in die Gereformeerde Kerken in Nederland, maar ook in Suid-Afrika na vore getree het (vgl. Coetzee 1988: 25-38).

Dan is daar die standaardwerk van Thiselton (2007) oor 'the Hermeneutics of Doctrine'. Thiselton (2007:xx) stel die volgende:

Biblical hermeneutics explores levels of meaning, strategies of reading, historical distance, appropriation, engagement, and formation, and often features patient and attentive listening. The relation between text, community, and tradition remains constantly in view. Can these habits of mind, with the historical, intellectual, and moral resources of hermeneutics, be placed at the service of understanding, exploring, appropriating, and applying Christian doctrine? (bl. $\mathrm{xx}$, [Thiselton se kursivering]) 
Thiselton (2007:xxii) gee aandag aan 'every area of doctrine ... in relation to its biblical roots, its historical development, and its practical significance for life'.

In onderskeid van bogenoemde beklemtonings word in hierdie artikel gefokus op konkrete (praktiese?) riglyne of reëls vir die lees en verklaring van die belydenisskrifte vanuit bepaalde hermeneutiese beginsels. Oor hierdie aspek is daar vir sover daar met 'n literatuursoektog met die hulp van die Ferdinand Postma-Biblioteek van die Noordwes-Universiteit vasgestel kon word, nog weinig gepubliseer.

\section{Die verhouding Skrif en belydenis}

In die reformatoriese tradisie word die nouste verband tussen die Woord en die belydenis gehandhaaf. Met verwysing na Matteus 16:13-19 wys Feenstra (1966:7) in die eerste plek daarop dat die belydenis deur die Woord van God geëis word. 'De gelovige heeft de roeping, zich rekenschap te geven van de waarheid, die ons in Gods Woord is geopenbaard.' Dit beteken nie dat die belydenis die onpeilbare rykdom van die Skrif volledig verwoord nie. Die Skrif is altyd ryker as die konfessies. Daar bestaan steeds die ruimte en moontlikheid om op grond van nuwe insigte die belydenis oor kernwaarhede van die Skrif uit te brei.

In die tweede plek is die belydenis op die Woord gegrond. Die Griekse woord vir 'belydenis' (homologia) beteken 'om dieselfde te sê'. 'Het karakter van de belijdenis is derhalve, dat zij gegrond moet zijn op de Schrift en geput moet worden uit Gods Woord' (Feenstra 1966:8). Feenstra (1966) wys ook daarop, met verwysing na Artikel 7 van die Nederlandse Geloofsbelydenis (NGB), dat die belydenis hierdie waarheid self erken. Die belydenisskrifte spruit uit die Woord en ontleen hulle gesag aan die Woord:

Die Woord het dus absolute gesag en die konfessies slegs afgeleide gesag. Maar juis omdat die konfessies gesag het norma normata teenoor die Skrif se norma normans - funksioneer hulle as rigsnoer vir alle teologiese denke - ook vir die verstaan van die Skrif. (Heyns \& Jonker 1977:142)

Die belydenis staan daarom nie bokant of langs die Woord (gelykstelling) nie. Nee, die ereplek (Feenstra 1966:8) van die belydenis is onder die Woord. Jonker (1994:28) wys op die primaat van die Woord en Van Genderen (s.j.:48) verklaar: 'Maar is de aanvaarding van een belijdenis als een kerkelijke norm een gelijkstelling van Schrift en belijdenis? Dat is een ernstig misverstand of een karikatuur van het gereformeerde standpunt.'

Die belydenis is dus altyd appellabel aan die Skrif. Die reformatoriese tradisie sien die belydenisskrifte nie as onfeilbare dekrete soos die Rooms Katolieke Kerk haar dogmas (belydenisskrifte) sien nie (Feenstra 1966:9). Wanneer die kerk in die lig en op grond van die Woord tot die oortuiging kom dat die belydenis op 'n bepaalde punt in stryd is met of afwyk van die Woord of die Woord verkeerd interpreteer, moet die belydenis op die bepaalde punt op 'n ordelike en kerklike wyse in ooreenstemming met die Woord gebring word.
Dit beteken aan die ander kant nie dat die belydenis op losse skroewe geplaas word nie; inteendeel, dit is die verskil tussen die sogenaamde quia- en quatenus-standpunt. Die kerk aanvaar die belydenisskrifte omdat (quia) dit met die Woord ooreenstem en nie in soverre (quatenus) dit ooreenstem met die Woord nie. Die onus rus op diegene wat die belydenis wil verander om die kerk vanuit die Woord te oortuig van die noodsaak vir verandering.

Praamsma (1971:67) haal die bekende Abraham Kuyper aan wat die belydenis bestempel het as die enigste kompas vir die kerk om haar veilig deur velerlei Woorduitleggings die waaragtige betekenis van die Woord in te lei. Sonder om ooit, onder watter vorm ookal, die belydenis met God se Woord as geheel op gelyke vlak te stel, handhaaf die kerk haar oortuiging dat die belydenis die allereenvoudigste en, voorasnog, die mees volkome bereikbare uitdrukking is van die 'volheerlijke waarheid' wat God aan ons geopenbaar het.

\section{Aard van die belydenisskrifte}

Die onderwerp van hierdie artikel vereis dat daar ook opnuut kortliks rekenskap gegee word van die aard van die belydenisskrifte.

In die eerste plek het ons in die belydenisskrifte met geskrewe dokumente te doen. Aanvanklik is dit geskryf in die tale van destyds (Grieks, Latyn, Duits, Frans en Nederlands) en later vertaal in menige wêreldtale, onder andere ook in Afrikaans.

In die tweede plek is die belydenisskrifte kerklike dokumente, gebaseer op die Skrif. Die taal waarin dit geskryf is, is geloofstaal.

Thiselton (2007:xvii) verwys verder na Gadamer vir wie hermeneutiek rekening hou met (draws on) gemeenskaplike verstaan en oorgelewerde wysheid, 'just as Christian doctrine is not simply a matter of individual belief but also of communal understanding, transmitted traditions, wisdom, commitment and action'.

Die belydenisskrifte is dus ook ekumenies van aard. Dit wou (veral in die tyd van die Reformasie) nie net teruggryp na en aansluit by die vroeë kerk nie, maar dit word ook aanvaar deur die mees moontlike aantal kerkgemeenskappe van dieselfde geloofstradisie.

Jonker (1994:11) wys ook op die teologiese aard van die belydenisskrifte. '... klaarblyklik het ons in die reformatoriese belydenisse te doen met die behoefte aan 'n sorgvuldig geformuleerde teologiese uiteensetting van wat die kerk glo'. Teologie moet myns insiens hier dan nie in die streng wetenskaplike sin van die woord verstaan word nie.

Wat die aard van die belydenisskrifte betref, is dit ook van die grootste belang om die werk van die Heilige Gees in gedagte te hou. Praamsma (1971:67) verwys na Barth (vgl. sy Church Dogmatics van 1956, bl. 624, 625) wat verklaar dat die belydenis die resultaat is van 'n ontmoeting van die kerk 
met die Heilige Gees. Dan haal Praamsma (1971) ook vir Abraham Kuyper aan uit Tractaat van de Reformaties der kerken, bladsy. 26:

Die belijdenis ontvangt de kerk dus niet als gedachtenvrucht van geleerde denkers, maar als dierbaar kleinood door den Heiligen Geest haar in de zielsworstelingen der geloovigen en in de bange nooden der kerk heerlijk toebereid. (bl. 67)

Wat die Skrif betref, word die besondere inspirasie van die Heilige Gees as eintlike Outeur in die reformatoriese tradisie beklemtoon. Wat die belydenisskrifte betref, moet die illuminasie (verligtende leiding) van die Gees beklemtoon word. Kerklike vergaderings of konsilies in die reformatoriese tradisie bely hulle afhanklikheid van die lig van die Woord en Gees in hulle besluitneming. Wat die formulering van die belydenisskrifte betref, is die belofte van Christus in Johannes 16:13 dat die Gees ons in die hele waarheid sal lei, myns insiens, in besondere sin van toepassing. Gereformeerde kerkvergaderings wat saam in biddende afhanklikheid besin oor die handhawing van die 'gesonde leer' (1 Tim 1:10, 11; 6:3; Tit 1:9; 2:1), kan dus met vrymoedigheid bevestig: 'Die Heilige Gees en ons het besluit ...' (Hand 15:28). Hiermee word die leiding van die Gees nie tot die gereformeerde tradisie alleen beperk nie.

Wat die aard van die belydenisskrifte betref, moet, in aansluiting by die vorige paragraaf, ook steeds in gedagte gehou word dat die belydenisskrifte oor die kernwaarhede van die geloof (die sg. capita doctrinae of hoofwaarhede) handel. Wat die hermeneutiek van die belydenisskrifte betref, is dit' $n$ belangrike faset waarna in die betrokke onderafdeling teruggekom sal word. In elke artikel of onderafdeling van die belydenis gaan dit oor ' $n$ spesifieke aspek van die leer. Belydenisskrifte handel oor die ware of suiwer leer teenoor die valse leer of kettery.

Die belydenisskrifte is daarom gesagvol en bindend. Heyns (1977:165) verklaar kategories: 'Wie belydenis sê, sê binding, meer nog: sê afdwingbare binding.' Strauss (2006:650) verwys in hierdie verband na die ondertekeningsformulier waarop die sinode van Dordrecht in 1618-1619 besluit het en wat steeds geldig is (vgl. verder ook Coetzee 2010:41, 42).

\section{Hermeneutiek van die Skrif en die belydenisskrifte}

Aan die begin van hierdie artikel is reeds instemmend daarop gewys dat 'n bepaalde Skrifbeskouing deurslaggewend is vir die verklaring (hermeneutiek) van die Skrif (Jordaan 1991). Net so kan die stelling gemaak word dat 'n bepaalde Skrifbeskouing ook van deurslaggewende belang is by die interpretasie van die belydenisskrifte (vgl. onder andere Coetzee 1988:26). 'n Bepaalde opvatting oor die interpretasie van die belydenis en 'n bepaalde Skrifbeskouing is onlosmaaklik aan mekaar verbonde. Ter bevestiging van hierdie stelling kan as voorbeeld verwys word na die geskiedenis in die (destydse) Gereformeerde Kerken in Nederland (GKN) waar die vraag na die interpretasie van en binding aan die belydenis juis in die kollig geplaas is deur die diskussie oor die aard van die Skrifgesag.

In Suid-Afrika bevestig die studieprojek deur die Instituut vir Teologiese Navorsing van die Universiteit van SuidAfrika oor die ontstaan, Skrifgebruik en gebruik van die NGB ook die waarheid van die stelling dat 'n bepaalde opvatting oor die belydenis en 'n bepaalde Skrifbeskouing moeilik van mekaar losgemaak kan word. So blyk dit telkens dat kritiek teen die Skrifgebruik en Skrifuitleg van die NGB net so van toepassing gemaak word op die Skrifgebruik enuitleg van die Skrif self, byvoorbeeld die gebruik en uitleg van bepaalde gedeeltes van die $\mathrm{Ou}$ Testament deur die Nuwe Testament (vgl. onder andere Bosman 1987:61, 63, 65, 67, 80).

In die gesprek tussen die Gereformeerde Kerke in SuidAfrika (GKSA), die Nederduitsch Hervormde Kerk van Afrika (NHK) en die Nederduitse Gereformeerde Kerk (NGK) het skynbare verskille (uiteenlopende standpunte) oor die God-mensverhouding in die Skrif (die inspirasie) op 'n stadium ook direk aanleiding gegee tot 'n besluit om aandag te gee aan klaarblyklike verskille in die nuansering van belydenisinterpretasie (Tussenkerklike Kommissie 1983:11).

As 'n laaste voorbeeld waar die hermeneutiek van die Skrif juis die verklaring van die belydenis bepalend beïnvloed, kan verwys word na Vögtle (1969). Die bydrae van Vögtle handel oor 'n nuwe verstaan van die artikel in die Apostolicum 'opgevaar het na die hemel'. Dit is duidelik dat Vögtle (1969) die hemelvaart nie as ' $n$ historiese gebeurtenis aanvaar nie.

Hoe kan men nu nog in ernst aannemen dat 'opgevaren is ten hemel'? In de eeu van de ruimtevaart weten wij het nog zekerder dan ooit tevoren: de aarde is een kogel en niet een schijf waarboven zich als het ware een bovenverdieping als de massieve bouw van het firmament, met de troonzaal Gods, zou uitstrekken. (bl. 50)

Volgens Vögtle (1969:52) wou die evangelis Lukas dus, en hieruit blyk sy Skrifbeskouing en -hantering met sy twee weergawes van die 'hemelvaart' (Luk 24 en Hand 1), die betekenis van Jesus se opstanding en van die verhoging van Jesus onder bepaalde aspekte aanskoulik en duidelik meedeel (verhaal). Uiteindelik vra Vögtle (1969) dan ten opsigte van die Apostolicum die vraag:

zou men eigenlijk niet ons artikel van die geloofsbelijdenis opnieuw moeten formuleren, wanneer ons 'opgevaren ten hemel' geen uiterlijke, aards-ruimtelijke gebeurtenis wil beschrijven, maar alleen een louter bovenaards gebeuren wil schilderen met behulp van de toenmalige opvatting dat de wereld opgebouwd was in drie verdiepingen? (bl. 55)

Sy antwoord is dat die formulering van die Apostolicum behou word as 'n 'symbolische, sacrale uitdrukkingswyse' wat teruggaan op die taal van die profete in die Ou Testament (Vögtle 1969).

By wyse van samevatting en konklusie aan die einde van hierdie onderafdeling, kan die volgende gestel dus word: 
'n Bepaalde Skrifbeskouing is uiteindelik deurslaggewend vir die verstaan en verklaring van die belydenisskrifte. Waar die belydenisskrifte hulle ontstaan gehad het in 'n bepaalde kerklike en teologiese tradisie, sal die Skrifbeskouing en -hantering van daardie tradisie dus bepalend wees vir die korrekte verstaan en verklaring van die belydenis. So kan die NGB byvoorbeeld nie vanuit ' $n$ ander Skrifbeskouing verstaan en verklaar word as die Skrifbeskouing wat in die NGB self (Art. 2 tot 7) bely word nie. Dieselfde geld ook vir die ander belydenisskrifte. ${ }^{5}$

\section{Hermeneutiek van die belydenisskrifte: Relevante reëls of riglyne}

Dit is belangrik om in gedagte te hou dat die belydenisskrifte as sodanig reeds verklarend is. Heyns en Jonker (1977:142) stel dat die belydenisskrifte gesien kan word as die kerk se gesaghebbende kommentaar op die Skrif.

Die belydenisskrifte kan en moet op hulle beurt egter ook verklaar word in dié sin dat daar terugverwys word na die Skrifgedeeltes op grond waarvan die belydenis geformuleer is, dat die belydenistaal in eenvoudige, eietydse taal 'vertaal' word, dat die lyne deurgetrek word na die praktyk, ensovoorts.

Hieronder volg nou 'n aantal 'konkrete' reëls of riglyne wat toegepas behoort te word met die oog op die korrekte verstaan en verklaring van die belydenisskrifte.

\section{Vertaling uit oorspronklike tale}

Daar moet in die verklaring van die belydenisskrifte steeds rekening gehou word met die feit dat die belydenisskrifte oorspronklik onderskeidelik in Grieks (ekumeniese belydenisskrifte), Latyn (Dordtse Leerreëls), Duits (Heidelbergse Kategismus), Frans en Nederlands (NGB en Dordtse Leerreëls) geskryf is. Sake soos woordorde, werkwoordsvorme en die gebruik van lidwoorde en voornaamwoorde kan in die oorspronklike taal 'n bepaalde betekenisinhoud aan 'n belydenisartikel gee. Sekere woorde kan ook in die oorspronklike taal 'n wyer of meer bepaalde betekenis hê as wat byvoorbeeld in 'n Afrikaanse vertaling tot sy reg kan kom. Kennis en gebruik van die oorspronklike tale kan dus verhelderend en verrykend inwerk op die verstaan en verklaring van die belydenisskrifte.

\section{Skrifgebruik}

Hierbo (vgl. onder die opskrif 'Verhouding Skrif en belydenis') is reeds besondere aandag gegee aan die verhouding tussen die Skrif en die belydenis. Die belydenisskrifte is gegrond op en spruit uit die Woord. Dit is 'n gelowige 'nasê' van die Woord. By die verklaring van die belydenisskrifte is dit daarom van kardinale belang dat rekening gehou word met die Skrifgebruik deur die oorspronklike opstellers. Daar moet wisselwerking wees tussen Skrif en belydenis. Daar moet 'gekontroleer' word of en hoe die beginsels van suiwer Skrifverklaring (gereformeerde hermeneutiek) toegepas is in die 'verklaring' van die Skrif in belydenistaal. Dit is juis in hierdie opsig dat 'n publikasie soos dié van Bosman (1987) krities gekyk het na die Skrifgebruik van die NGB. Op grond van moderne Skrifuitleg (wat grondig verskil van die tradisionele reformatoriese Skrifuitleg), word dan juis kritiek ten opsigte van die NGB uitgespreek dat dit gebrekkige aandag toon vir die $\mathrm{Ou}$ Testament se oorspronklike literêre en historiese konteks (Bosman 1987:67). So verklaarScheffler (1987:80) byvoorbeeld, met verwysing na Artikel 23 van die NGB, dat die NGB Paulus se interpretasie van Psalm 32:2 in Romeine 4:8 onkrities oorgeneem het. Dit is noodsaaklik dat kritiek soos hierdie grondig geweeg en beoordeel word vanuit die reformatoriese Skrifbeskouing en gebruik.

\section{Die 'taal' of genre van die belydenisskrifte}

Dit is verder belangrik dat ook die taal of genre van die belydenisskrifte in ag geneem word by die verklaring. Wat die hermeneutiek van die Skrif betref, is dit van kardinale belang om byvoorbeeld te onderskei tussen historiese stof, poëtiese stof, profetiese stof, apokaliptiese stof, ensovoorts. By die hermeneutiek van die belydenisskrifte moet daar ook in 'n ietwat ander sin met 'n verskil in genre rekening gehou word. So het die NGB byvoorbeeld 'n ander Sitz im Leben as die Heidelbergse kategismus en Dordtse Leerreëls. Die Dordtse Leerreëls is op sy beurt meer leerstellig geformuleer as die Heidelbergse kategismus, ensovoorts.Verboom (1996:19) wys daarop dat die Heidelbergse kategismus antropologies-bevindelik van aard is. Van die NGB sê Verboom (1999:28) dat die belydenis apologeties, maar nie polemies is nie. Uiteindelik is Verboom (2005:257) van mening dat die NGB en die Heidelbergse kategismus as sleutel gebruik word by die lees van die Canones (Dordtse Leerreëls).

\section{Die paradigma van die belydenisskrifte}

Daar moet voortdurend rekening gehou word met die bepaalde paradigma waaruit die belydenisskrifte ontstaan het. So het die ekumeniese belydenisskrifte (Nicea, Apostolicum, Athanasium) vanuit die paradigma van die vroeë kerk ontstaan, terwyl die Drie Formuliere van Eenheid (NGB, Heidelbergse Kategismus en Dordtse Leerreëls) vanuit die paradigma van die sestiende-eeuse Reformasie ontstaan het - weliswaar in doelbewuste aansluiting en teruggrype na die paradigma van die Vroeë Kerk. Von Loewenich $(1969: 5,6)$ wys daarop dat die Reformasie ' $n$ vernuwing wou wees van die een ware Katolieke Kerk. Die paradigma-bepaalde teologie van die tyd (veral die dogmatiek en eksegese) was diensbaar aan die kerk met die oog op die uiteindelike formulering van die onderskeie belydenisskrifte. Die teks van die belydenis moet dus geplaas word binne die raamwerk van dít wat as tipiese kenmerke van die klassieke gereformeerde tradisie beskou is. 'n Verklaring van die belydenis vanuit ' $n$ ander paradigma (bv. Skrifkritiese of 
postmoderne paradigma) sal nie reg laat geskied aan die belydenis self en die werklike betekenis daarvan nie. Waar dit wel geskied, word daar enersyds gepleit vir verdraagsaamheid as sou die belydenis ruimte bied vir byvoorbeeld uiteenlopende standpunte oor die Skrifgesag (vgl. Coetzee 1988:33). Sodoende kom die binding aan die belydenis in die gedrang. Andersyds word die belydenis slegs gesien as 'n gemeenskaplike oriëntasiepunt van mense se geloof (vgl. Coetzee 1988:34). Ook hierdie opvatting raak die hele kwessie van die binding aan die belydenis. Dit impliseer 'n ander opvatting oor die wese en karakter van 'n belydenisskrif as wat in die verlede deur kerke van gereformeerde belydenis gehuldig is (Coetzee 1988:34).

Hier moet bygevoeg word dat, hoewel die een-en-twintigsteeeuse paradigma ook weer verskil van díe van die sestiende eeu, die kernwaarhede van die Skrif wat bely word, steeds dieselfde is.

\section{Eksegese}

Die belydenisskrifte moet ook as 't ware geëksegetiseer word. Dit hou in dat die betekenis van woorde en begrippe sorgvuldig nagegaan word. Dit beteken ook dat die gebruik van bepaalde of onbepaalde lidwoorde, voornaamwoorde, ensovoorts verreken word. So word byvoorbeeld in vraag en antwoord 24 van die Heidelbergse Kategismus juis die persoonlike voornaamwoord gebruik ('ons skepping ... ons verlossing $\ldots$ ons heiligmaking') omdat ons met 'n persoonlike belydenis te doen het (GKSA 2001:39). Eksegese hou ook in dat daar byvoorbeeld onderskeid gemaak word tussen hoofsinne en bysinne. 'n Goeie voorbeeld hiervan is die lang antwoord 26 van die Heidelbergse Kategismus. Die hoofsin van hierdie antwoord is relatief kort, naamlik 'Ek glo dat die ewige Vader van ons Here Jesus Christus ... ter wille van sy Seun Christus my God en Vader is.' In die res van die antwoord word daar uitgebrei op die almag en skeppingswerk van God asook wat dit beteken dat Hy 'my God en Vader' is.

\section{Quia of quatenus}

Daar is hierbo reeds kortliks verwys na die onderskeid tussen die quia- en quatenus-standpunte ten opsigte van die belydenisskrifte. In die Calvinisties-reformatoriese tradisie word die belydenisskrifte in die reël aanvaar omdat (quia) dit in ooreenstemming met die Woord is en nie slegs in soverre (quatenus) dit met die Woord ooreenstem nie. By die verklaring van die belydenis sal hierdie twee vooronderstellings of vertrekpunte onderskeidelik vanselfsprekend 'n deurslaggewende rol speel. In die geval van die quatenusstandpunt sal die belydenisskrifte uit die staanspoor 'bevraagteken' word en sal in elke geval eers vasgestel moet word of en in hoeverre die belydenis met die Skrif ooreenstem. In die geval van die quia-standpunt geld die vertrekpunt dat die belydenis die Skrifwaarheid korrek en suiwer saamvat, totdat daar vanuit die Skrif en met toepassing van die gereformeerde hermeneutiek aangetoon word dat die belydenis op 'n bepaalde punt nie met die Skrif in ooreenstemming is nie.

\section{Historiese konteks}

Die belydenisskrifte kan en mag nooit gelees word sonder om die historiese konteks waarin dit ontstaan het in ag te neem nie. In die geval van die belydenisskrifte gaan dit om die kernwaarhede van die leer en daarom verdien veral die dogmahistoriese agtergrond telkens besondere aandag (vgl. onder andere Hofmeyr \& Van Niekerk 1987:7-9). 'Belydenisskrifte vertoon die spore van die tyd en die konteks waarin hulle opgestel word' (Van Niekerk 1987:14). In die hermeneutiese ontsluiting van 'n belydenisskrif moet dit in ag geneem word (Van Niekerk 1987). So is die direkte agtergrond van 'n belydenisskrif soos die NGB (1561) byvoorbeeld die Wederdopers of Anabaptiste se standpunt. Hofmeyr en Van Niekerk (1987) verklaar in hierdie verband:

Die belangrikste probleem wat ... die NGB ten grondslag lê, is die Wederdopers of Anabaptiste ... Dit is juis die duidelike antidoperse instelling van die NGB wat hom van alle ander gereformeerde belydenisse onderskei. (bl. 2; vgl ook Verboom 1999:21-25)

Die belydenis van Nicea (325 n.C.) moet op sy beurt gesien word teen die agtergrond van die Gnostisisme en die dwaling van Arius, terwyl die Dordtse Leerreëls (1618-1619) opgestel is teen die Remonstrante. ${ }^{6}$

Wanneer ons dan dieselfde waarhede steeds in ' $n$ nuwe konteks bely, moet die relevansie van die belydenis in die huidige konteks telkens opnuut aangetoon en beleef word.

\section{Inhoudelike konteks}

In noue aansluiting by wat hierbo onder 'Historiese konteks' genoem is, verdien ook die inhoudelike konteks van die belydenis telkens besondere aandag ten einde by die korrekte verklaring uit te kom. Anders gestel: insig in die teologiese problematiek van die tyd is noodsaaklik vir die regte verstaan en verklaring van die belydenis. 'n Duidelike voorbeeld van wat hier bedoel word, vind ons byvoorbeeld in die hantering van beswaarskrifte teen bepaalde artikels van die NGB deur 'n sinode van die GKSA (vgl. GKSA 2003:492-502). In die eerste plek het daar 'n beswaarskrif gedien teen Artikel 15 van die NGB en veral teen die volgende sinsnede: 'Dit [die erfsonde] word selfs nie deur die doop geheel en al tot niet gemaak nie.' Die beswaardes het beweer dat hierdie sinsnede groot leerstellige probleme skep aangesien ons ook byvoorbeeld in die Heidelbergse Kategismus (vraag en antwoord 72) bely dat die uitwendige waterbad van die doop nie self die sondes afwas nie. In sy antwoord op die beswaarskrif het die sinode (GKSA 2003) in die eerste plek verwys na die leer van Rome:

Rome beskou die doop as die oorsaak van die heil. Daarom is en word daar steeds geleer dat die sonde deur die doop weggeneem word; nie slegs die erfsonde nie, maar ook die daadsonde. (bl. 495)

Daarna verwys die sinode (GKSA 2003) na die standpunt van die Reformatore wat lynreg teenoor díe van Rome staan.

$6 . V i r$ 'n volledige behandeling van die historiese agtergrond en die teologie van die Dordtse Leerreëls, waarvoor daar in hierdie artikel ongelukkig nie ruimte is nie, kan verwys word na Verboom (2005). 
'Hulle het gesê dat die genade van die doop tweevoudig is: ons word in die doop sowel die vergewing van sondes as die wedergeboorte aangebied.' Die wedergeboorte begin en gaan dwarsdeur die hele lewe voort. Uiteindelik bevind die sinode (GKSA 2003) dat:

Dit is juis met hierdie woorde uit NGB artikel 15 ... dat Guido de Brés die Reformatoriese standpunt teenoor die Roomse standpunt stel. Wat hierdie woorde dus in positiewe sin sê, is dat in die wedergeboorte en vergewing van sondes (wat in die doop afgebeeld en aangebied word) wel die skuld van die sonde weggeneem is, maar nie die smet daarvan nie. (bl. 495)

'n Tweede beswaarskrif het by dieselfde sinode gedien teen die sinsnede in artikel 24 van die NGB: ' ... dat die geloof hom wedergebore laat word ...' (vgl GKSA 2003:497-502). Die beswaardes het onder andere beweer dat 'Die "geloof" kan nie die handelende subjek wees wat die mens wederbaar, tot 'n nuwe mens maak en hom 'n nuwe lewe laat lei nie' (GKSA 2003:497); dat dit die Gees is wat die mens wederbaar (bl. 498); dat ander belydenisuitsprake en ook die Skrif die wedergeboorte vóór die geloof stel (bl. 499). In sy antwoord op hierdie beswaar stel die sinode dan onder andere die volgende (GKSA 2003):

Eerstens: die NGB is in 1561 opgestel toe die stryd teen die Roomse Kerk op die voorgrond gestaan het. Die Reformasie het 'die regverdiging deur die geloof alleen' sterk beklemtoon teenoor die Roomse regverdiging deur die geloof en goeie werke. Die Reformatore het die klem geplaas op die eerste daad van die Heilige Gees waarvan die mens bewus is, naamlik die geloof en wat daaruit voortvloei ... Die Dordtse vaders was weer gerig teen die Remonstrantisme wat die geloof grotendeels as die menslike prestasie gesien het ... Tweedens: Beide die NGB, art. 24 en die DL 3/4:12, 13 gaan terug na Calvyn. In sy kommentaar op Joh 1:12 verduidelik Calvyn dat Johannes ons leer dat die mag (om kinders van God te word) gegee word aan diegene wat reeds glo en die wat glo, reeds uit God gebore is. (bl. 500, 501)

Uiteindelik bevind die sinode (GKSA 2003):

Die NGB fokus dus op die eerste bewustelike vrug van die wedergeboorte, naamlik die geloof wat die wedergeboorte voortsit in regverdiging en heiliging. Die DL fokus op die verborge oorsprong van die geloof, die wedergeboorte en onderskei met fyner nuanses. Hier is dus nie 'n prinsipiële verskil nie, maar' $n$ verskil in beklemtoning. (bl. 501)

'n Verdere aspek wat ten opsigte van die inhoudelike konteks in gedagte gehou moet word, is dat 'n bepaalde artikel of onderafdeling in die konteks van die geheel gelees moet word (in die geval van die hermeneutiek van die Skrif beteken dit datSkrifmetSkrifvergelykword). Dit is veral in belydenisskrifte soos die Heidelbergse Kategismus en die Dordtse Leerreëls sonder meer duidelik hoe dat die een vraag en antwoord of paragraaf volg op die vorige en lei tot die volgende - totdat die geheel uiteindelik'n organiese eenheid vorm.

\section{Sentrum en periferie}

Hierbo is dit reeds gestel dat die belydenisskrifte die kernwaarhede van die leer saamvat en dat elke artikel of onderafdeling oor 'n bepaalde leerstellige waarheid handel.
Dit impliseer dat by die verklaring van die belydenis daar telkens tussen hoofsaak en bysake onderskei moet word. Anders gestel: die onderskeid tussen sentrum en periferie moet deeglik verdiskonteer word.

'n Voorbeeld van hoe hierdie hermeneutiese riglyn of reël toegepas behoort te word, vind ons in artikel 4 van die NGB (GKSA 2001:6). In hierdie artikel word die lys van die Bybel se kanonieke boeke genoem. Die brief aan die Hebreërs word dan onder die briewe van Paulus geplaas, terwyl dit algemeen aanvaar word dat Paulus nie die skrywer daarvan is nie. Nou is daar diegene wat hierdie 'fout' in die belydenis gebruik om die belydenis te bevraagteken of as onbetroubaar af te maak. Wanneer die relevante hermeneutiese riglyn of reël egter toegepas word, is dit sonder meer duidelik dat artikel 4 handel oor watter boeke deel van die kanon is en nie oor wie die skrywers was nie. Artikel 4 moet gelees word in samehang met artikel 5 ('Ons aanvaar al HIERDIE boeke EN HULLE ALLEEN as heilig en kanoniek'; GKSA 2001:6, 7, [outeur se beklemtoning]) en met artikel 6 (die onderskeid tussen die kanonieke en die apokriewe boeke; GKSA 2001:7).

\section{Die werk van die Heilige Gees}

Wat die hermeneutiek van die belydenisskrifte betref, is die belangrikste reël uiteindelik dat die grootste erns gemaak word met die werk van die Heilige Gees. Wat die heilige Skrif betref, aanvaar die reformatoriese tradisie die onmisbare werk van die Heilige Gees (as auctor primarius) in die inspirasie en in die verkondiging. Wat die belydenisskrifte betref, moet die erkenning van die verligtende werk van die Gees (illuminasie) gehandhaaf word ten opsigte van die vasstelling asook die verklaring daarvan. Daarom moet die hermeneutiek van die belydenisskrifte altyd deur biddende afhanklikheid van die Heilige Gees beheers word.

\section{Konkluderende opmerkings}

By wyse van samevatting en konklusie kan die volgende gestel word: In die reformatoriese tradisie word die belydenisskrifte as deel van die wese van die kerk gesien en steeds as sodanig gehandhaaf. Die kernwaarhede wat daarin bely word, is steeds aktueel en relevant. Die dwalinge waarteen dit oorspronklik deur die kerke vasgestel is, is ook steeds en opnuut aan die orde.

Die gevaar bestaan egter dat die belydenisskrifte steeds meer as gedateerde dokumente gesien en hanteer word en/of dat die binding aan die belydenis stelselmatig verslap word. Janse van Rensburg en Dreyer (2016, ter perse) wys in hierdie verband daarop datneigingsom afstand teneem vandiegeloofsbelydenis, die eenheid, kohesie en identiteit van die kerk bedreig.

Aan die vooraand van die vyfhonderdjarige herdenking van die sestiende-eeuse Reformasie is dit wesenlik belangrik dat die belydenisskrifte steeds as lewende belydenis van reformatoriese kerke sal funksioneer. ' $n$ Prinsipieel-begronde hermeneutiek met konkrete en relevante riglyne kan hierin van besondere hulp wees. 
Wat die hermeneutiek betref, het prof Gert Jordaan in sy vakgebied (Nuwe-Testamentiese wetenskappe) 'n navolgenswaardige voorbeeld gestel en baanbrekerswerk verrig. Die dogmatiek kan met groot vrug van die relevante aspekte van sy werk gebruik maak in die uitbouing van 'n hermeneutiek van die belydenisskrifte.

\section{Erkenning \\ Mededingende belange}

Die outeur verklaar dat hy geen finansiële of persoonlike verbintenis met enige party het wat hom nadelig of voordelig kon beïnvloed het in die skryf van hierdie artikel nie.

\section{Literatuurverwysings}

Bosman, H.L., 1987, 'Die gebruik van die Ou Testament in die Nederlandse geloofsbelydenis', in H.L. Bosman, J.W. Hofmeyer, E.H. Scheffler, I.J. van Eeden \& E. van Niekerk (reds.), Die Nederlandse geloofsbelydenis: Ontstaan, Skrifgebruik en Gebruik, bl. 53-69, Universiteit van Suid-Afrika, Pretoria.

Coetzee, C.F.C., 1988, 'Die interpretasie van die belydenis', in P.J. de Bruyn (samest.), Waar die paaie saamwoon: Bundel wetenskaplike opstelle aangebied aan prof. P.W. Buys by sy emeritering as hoogleraar, bl. 25-38, Potchefstroomse Teologiese Publikasies, Potchefstroom.

Coetzee, C.F.C., 2010, 'Belydenisgebondenheid in 'n postmoderne era', In die Skriflig $44(1), 27-45$

Coetzee, C.F.C., 2013, 'Kerk en belydenis', Tydskrif vir Christelike Wetenskap 49(4), 275-293.

Du Plooy, A le R., 1982, 'Kerkverband: 'n gereformeerd-kerkregtelike studie', DPhilproefskrif, PU' vir CHO, Potchefstroom.

Feenstra, J.G., 1966, Onze geloofsbelijdenis, Kok, Kampen.

Gereformeerde Kerke in Suid-Afrika, 2001, 'Belydenisskrifte en Liturgie', in Gereformeerde Kerke in Suid-Afrika, Psalmboek: die berymde en omgedigte psalms en ander skrifberymings, pp. 1-188, NG Kerk-Uitgewers, Wellington.

Gereformeerde Kerke in Suid-Afrika, 2003, Handelinge van die agt-en-veertigste Nasionale Sinode te Potchefstroom op 6 Januarie 2003 en volgende dae en tweede addendum van die Emeritaatsversorgingskombinasie, GKSA, Potchefstroom.

GKSA sien Gereformeerde Kerke in Suid-Afrik

Heyns, J.A., 1977, Die kerk, NG Kerkboekhandel, Pretoria.

Heyns, J.A. \& Jonker, W.D., 1977, Op weg met die teologie, NG Kerkboekhandel, Pretoria.

Hofmeyr, J.W. \& Van Niekerk, E., 1987, 'Die Nederlandse geloofsbelydenis: Konteks en teks', in H.L. Bosman, J.W. Hofmeyer, E.H. Scheffler, I.J. van Eeden \& E. van Niekerk (reds.), Die Nederlandse geloofsbelydenis: Ontstaan,Skrifgebruik en Gebruik, bl. 1-13, Universiteit van Suid-Afrika, Pretoria.
Janse van Rensburg, A. \& Dreyer, W., 2016, 'Die funksie en doel van die Apostoliese Geloofsbelydenis', HTS Teologiese Studies/Theological Studies, 72(3). (ter perse).

Jonker, J.D., 1994, Bevrydende waarheid: Die karakter van die gereformeerde belydenis, Hugenote Uitgewers, Wellington.

Jordaan, G.J.C., s.j., Nuwe Testament: Gereformeerde hermeneutiek en hermeneutiese strominge, Leesbundel vir HERM875A, Fakulteit Teologie, Teologiese Skool van Potchefstroom, Potchefstroom.

Jordaan, G.J.C., 1991, Skrifbeskouing: deurslaggewende faktor by Skrifverklaring, Departement Sentrale Publikasies, Potchefstroom. (Wetenskaplike bydraes, PU vir $\mathrm{CHO}$, Reeks H, Inougurele Rede, 125).

Jordaan, G.J.C., 2015, Samevattende opsomming van leerinhoud van seminare 1-12, HERM875, Fakulteit Teologie, Teologiese Skool van Potchefstroom, Potchefstroom

Lategan, B.C, 2008, 'Hermeneutiek', in F. Gaum, A Boesak \& W Botha (reds.), Christelike kernensiklopedie, bl. 449-450, Lux Verbi, Wellington.

Müller, J., 2006, 'Teologie voor nuwe kairos-oomblik', Die Kerkbode, 11 November, bl. 5.

Praamsma, L., 1971, Met de kerk van alle eeuwen: Over confessionele trouw en ontrouw, Buijten \& Schipperheijn, Amsterdam.

Scheffler, E.H., 1987, 'Die gebruik van die Nuwe Testament in die Nederlandse geloofsbelydenis', in H.L. Bosman, J.W. Hofmeyer, E.H. Scheffler, I.J. van Eeden \& E. van Niekerk, (reds.), Die Nederlandse geloofsbelydenis: Ontstaan, Skrifgebruik en Gebruik, bl. 70-88, Universiteit van Suid-Afrika, Pretoria.

Snyman, G., 2007, Om die Bybel anders te lees: ' $n$ etiek van Bybellees, Griffel, Pretoria.

Sproul, R.C., 2006, The triune God: Chapters 1-8 of the confession, P\&R Publishing, Phillipsburg.

Strauss, P.J., 2006, 'Die Dordtse tradisie en binding aan die belydenis', In die Skriflig 40(3), 649-666.

Thiselton, A.C., 2007, The hermeneutics of doctrine, Eerdmans, Grand Rapids, Mich.

Tussenkerklike Kommissie, 1983, 'Notule van vergadering, 10 Augustus 1983', geargiveer.

Van Genderen, J., s.j., De reformatorische belijdenis in discussie, Buijten \& Schipperheijn, Amsterdam.

Van Niekerk, A.A., 2005, Geloof sonder sekerhede: Besinning vir eietydse gelowiges, Lux Verbi, Wellington.

Van Niekerk, E., 1987, 'Die hermeneutiese sleutel van die Nederlandse Geloofsbelydenis', in H.L. Bosman, J.W. Hofmeyer, E.H. Scheffler, I.J. van Eeden \& E. van Niekerk, (reds.), Die Nederlandse geloofsbelydenis: ontstaan, skrifgebruik en gebruik, bl. 14-28, Universiteit van Suid-Afrika, Pretoria.

Verboom, W., 1996, De Theologie van de Heidelbergse Catechismus. Twaalf Thema's: De Context en de latere uitwerking, Uitgeverij Boekencentrum, Zoetermeer.

Verboom, W., 1999, Kostbaar belijden: De theologie van de Nederlandse Geloofsbelijdenis, met preekschetsen, Uitgeverij Boekencentrum, Zoetermeer.

Verboom, W., 2005, De belijdenis van een gebroken kerk: de Dordtse leerregels, voorgeschiedenis en theologie, Uitgeverij Boekencentrum, Zoetermeer.

Vögtle, A., 1969, 'Opgevaren ten hemel', in Anon, De geloofsbelijdenis: Pogingen to een nieuw verstaan, transl. J. van de Geyn, bl. 50-55. Bosch \& Keuning, Baarn.

Von Loewenich, W., 1969, 'Ontstaan en betekenis van de apostolische belijdenis', in Anon, De geloofsbelijdenis: Pogingen tot een nieuw verstaan, transl. J. van de Geyn, bl. 5-9, Bosch \& Keuning, Baarn. 